\title{
LEARNING AND REVIEWING VOCABULARY THROUGH MEMRISE TO IMPROVE STUDENTS' VOCABULARY ACHIEVEMENT
}

\author{
Dian Fadhilawati \\ Universitas Islam Balitar, Blitar, East Java Indonesia \\ Email: dianfadhilawati@ unisbablitar.ac.id
}

\begin{abstract}
This article dealt with classroom Action Research which intended to improve the vocabulary achievement of 39-second semester students of Faculty of Agriculture and Animal Husbandry at the Islamic University of Balitar by using Memrise. In this research, the students learned 3 levels of agriculture and vocabulary prepared and created by the lecturer in www.memrise.com. In order to have a good vocabulary achievement, the students are asked to learn the vocabulary in the classroom and review it at home through Memrise Application. The data of the research were collected from tests and questionnaire. This research was conducted in one cycle of action which covered (1) Planning, (2) Acting, (3) Observing and (4) Reflecting. The result of the research showed that the implementation of Memrise as learning and reviewing vocabulary tool could improve the students' vocabulary achievement from the mean score 60.45 (Pretest) to 86.27 (Post-test). Moreover, the result of the research was strengthened by the student's positive responses toward the use of Memrise as learning and reviewing vocabulary tool as reflected from the result of the questionnaire given.
\end{abstract}

Keywords: Memrise, Learning and Reviewing Vocabulary, Vocabulary Achievement, Action Research.

Received: 24 June, 2016; Accepted: 8 September, 2016

\section{INTRODUCTION}

Teaching English especially for Non-English Department students in Indonesia are generally through two-course models, the first is GE (General English) and the second is ESP (English for Specific Purpose) (Cahyono, 2011, p.147). The second-semester students of nonEnglish Departments especially at Faculty of Agriculture and Animal Husbandry at the Islamic University of Balitar learn English through English for Specific Purpose (ESP). In this course, they must learn four skills (Speaking, Writing, Reading, and Listening) which related to their field. Therefore, to support their understanding about the materials that will be given by the lecturer in Teaching and Learning process, and to help them achieve a good achievement in ESP course, mastering vocabulary which related to the students' subject is really important for them.

Schmitt and McCarty (1997, p.6) argue that vocabulary has a pivotal role for students in mastering English language skills for examples: in listening, vocabulary gives the students 
easiness to comprehend what the other person speaks. In speaking and writing, vocabulary gives the students easiness to develop their ideas. In reading, vocabulary gives the students easiness to comprehend the reading text. Therefore, vocabulary must not be ignored by the students who learn English. There are some reason why the students must learn vocabulary such as 1) lack of vocabulary, will make them difficult to follow or grasp the lecturer's explanation, 2) limited vocabulary will make them become passive students in the classroom, for examples when the lecturer ask them questions they cannot answer appropriately or feel unconfident to answer.

Moreover, Kwelju (1997) cited in Choyimah (2011, P.195) argues that the students of the English Department at 15 teacher colleges in some areas in Indonesian students have 4664 base words and 2800 family words. This number is not enough to comprehend the text, because in order to be able to read the text comprehensively the students need at least 5000 words if the students of English Department can have such of lack vocabulary, and what about the students who come from non-English Department?

The condition of lack vocabulary happened in my ESP classroom, it made the students difficult to follow the lesson especially to comprehend the reading texts which requires them to understand more specific or technical terms related to their field. It was proved by the students' result of pre-test (test before the action) in which belongs to unsatisfying. In this case, the student's mean score of vocabulary achievement at Faculty of Agriculture and Animal Husbandry in the 2015/2016 academic year was 60.45 . That result was below the minimum criterion mastery of the subject (75.00). Therefore, the lecturer tried to solve the students' low achievement on vocabulary by making her own vocabulary course in www.memrise.com. The course contains some words or phrases that the students need in the order they can able to understand the texts which related to agriculture and farming, as well as animal and plant breeding.

In this research, there were two research problems; 1) how can learning and reviewing vocabulary through Memrise improve the students' vocabulary achievement? And 2) how the students' responses toward the application of Memrise in learning and reviewing the vocabulary? Based on the problem, the objective of the research was to use memrise as learning and reviewing vocabulary tool to improve the students' vocabulary achievement.

There were some reasons why the lecturer used Memrise as media to solve the low vocabulary of the students such as it works based on several important scientific discoveries about how the students learn. First, using the system of Memes (mnemonics and memory aids) promotes elaborate encoding- encouraging the learning brain to do more by engaging the imagination, and thus helping to remember vocabulary better in an effective manner. Secondly, Memrise makes use of Spaced Repetition, it will help the students review words at expertly spaced intervals and maintain them in their memory effectively. Memrise Reminders us when time to learn or to review our course, therefore it will give the students motivation to learn and make them don't forget about the time when they must learn or review the vocabulary (www.memrise.com). Furthermore, researchers such as Walker (2016) argues that "the students found using Memrise enjoyable and convenient, and would be a useful tool for teachers in teaching vocabulary 


\section{Vocabulary Definitions}

There are some definitions of vocabulary, Burn (1972) cited in Alqahtani (2015, p. 25) defines vocabulary as the collection of words which are used by a person, class or profession, in addition, Ur (1998) cited in Alqahtani (2015, p.25) defines vocabulary as the words that we teach in the foreign language in this case, the vocabulary could consist of more than one word: for example, post office, and mother-in-law, which is consisted of two or three words but express one idea, furthermore, vocabulary can be defined as knowledge of words and what they mean either oral vocabulary or reading vocabulary. Students learn vocabulary through a variety of contexts such as talking, interacting, and playing with others; listening to stories; watching television and attending school (https://iris.peabody.vanderbilt.edu/module/rti03reading/cresource/q3/p07).

In this research, vocabulary referred to words or phrases that should be mastered by the second-semester students of Agriculture and Animal Husbandry at the Islamic University of Balitar in the order they can comprehend the text easily. There were 44 vocabularies prepared by the lecturer in vocabulary course at Memrise which was divided into 3 levels. Level 1 includes 15 words: Agriculture, Farmer, Farm, Breeding, Irrigation, Climate, Air, Soil, Mineral, Pesticide, Water, Fertile, Fertilizer, Crop, and Rice. In level 2 covers: Plant Breeding, Animal Breeding, Selective Breeding, Inbreeding, Breeder, Crossbreed, Hybrid, Mule, Maize, Extinction, Taxon, Species, Outcross, Labra-doodle, and Cultivar. And in Level 3 covers: Polyculture, Monoculture, Multiple Cropping, Intercropping, Aquaponics, Sustainable Agriculture, Permaculture, Organic Agriculture, Crop Rotation, Green Manure, Greenhouse, Compost, Horticulture, Raw Material and Pastoral Farming. (Further information, see at https://www.memrise.com/course/90393/agriculture-and-farming-vocabulary)

\section{The Importance of Learning Vocabulary}

Vocabulary mastery is the most important aspect for foreign language learners or second language learners. It is important for them in order to be able to communicate using target language fluently. By having enough vocabulary about the materials that will be discussed (for examples: reading text, video presentation, listening materials, presented by the lecturer in the classroom), the students' will be able to study or follow the lesson easily. In line with the statement above, Schmitt (2000, P. 55) argues that lexical knowledge is pivotal to the students' communicative competence. It means that if the students don't have enough vocabulary it will difficult for them to understand and produce the targeted language. Moreover, Nation (2001) describes the relationship between vocabulary knowledge and language use as complementary: knowledge of vocabulary enables language use and, conversely, language use leads to an increase in vocabulary knowledge. Therefore the students must use vocabulary as often as possible either in the classroom or outside of the classroom. 
Furthermore, there are many researchers who have pointed out that vocabulary acquisition has the important role for the students either in learning Second or Foreign languages. The researchers such as Laufer and Nation (1999), Maximo (2000), Read (2000) Gu (2003), Marion (2008) and Nation (2011) have realized that the acquisition of vocabulary is pivotal in determining the successfulness of second language use, and plays an important role in the formation of complete spoken and written texts. In English as a second language (ESL) and English as a foreign language (EFL,) learning vocabulary plays a vital role in facilitating the students' success in mastering four English language skills (i.e. listening, speaking, reading, and writing (Nation, 2011).

From the description of the importance of vocabulary above, it is clear that the students' acquisition of an adequate vocabulary has an important role in determining their successfulness in mastering the foreign language. In learning English the students rely heavily on vocabulary knowledge. Because by having adequate vocabulary they will learn others skill (Reading, Listening, Speaking and Writing) easily. In this research, by mastering vocabulary related to the students' field, it will determine the students' successfulness in learning ESP subject.

\section{Learning and Reviewing Vocabulary through Memrise}

\section{Memrise Definition}

Memrise in www.memrise.com is defined as an online learning community where we can learn almost anything especially language mostly for free. It is the right mix of science, fun, and community. Learning on Memrise is speedy, enjoyable and lasts.

Furthermore, Memrise is founded in 2010 by Grandmaster of Memory, Ed Cooke and Princeton neuroscientist, Greg Detre in 2010, Memrise is a free online learning platform which takes the very best science of learning and combines it with engaging, playful design to make word-learning fun, fast and exceedingly effective. It uses the latest cognitive science to help you learn up to five times faster. Over the last four years, Memrise has helped more than 2.5 million people to learn more than 400 different languages. (http://www.prnewswire.com).

Moreover, Fisher (2016) reviews Memrise as free language learning website that uses its community of users to teach and improve language learning for everyone involved. It uses audio, images, and memory techniques to help us associate words with one another for easier recall, as well as regular tests to ensure we are remembering the concepts.

In this research, Memrises was used by the researcher to make free vocabulary course about Agriculture and farming vocabulary which the students can learn in the classroom and review it at home. The students would have fun learning because they studied vocabulary like playing a game. Further information about the researcher vocabulary course, please see at https://www.memrise.com/course/90393/agriculture-and-farming-vocabulary) 


\section{The Reasons why Memrise Suitable for Learning and Reviewing Vocabulary}

Learning and reviewing vocabulary regularly is the process in determining the students' achievement especially in learning language. Macaro (2001) argues that the students' should have more practice to have a good vocabulary acquisition. Besides, learning vocabulary in their classroom they should have time for reviewing the lesson at home. In this case, Memrise as Online learning and reviewing tool uses spaced repetition methods which store the students' memorized data and assess the knowledge according to this data, it would give benefit for them to have a long-term memory to what they have learned

Furthermore, Besides Memrise uses Spaced Repetition there are some other reasons why Memrise suitable for learning and reviewing vocabulary that the researcher grasped from www.memrise.com

\section{Memrise was made based on several important scientific discoveries about how we learn.}

In this case, Memrise uses a System of Memes. Choreographed Testing, and Scheduled reminders. The detail description as follows:

\section{a. Memrise uses a System of Memes}

Memrise Uses Memes (mnemonics and memory aids) made by the community or it usually called as Mems-makers. Memes in Memrise can be mnemonics, etymologies, amusing videos, photos, pictures, example sentences or anything which helps the students connect with what they are learning. By applying Memes in the students' learning, it will help them have a good memory in their brain, promote elaborate encoding which- encourage their learning brain to do more by engaging their imagination. In this case, the more the students' brain encodes the word, the better their memory. In this research, the researcher who made vocabulary course or the students' who learned vocabulary could provide memes in their vocabulary course in www.memrise.com. Dealing with memes in Agriculture and Farming vocabulary for examples; the researcher provided the students with pictures to know what is the breeder, labradoodle, mule etc.

\section{b. Choreographed Testing}

Recalling memories is very important for the students as they have strong and powerful memory in their brain. By using Memrise the students will have fun recalling process to what they have learned. In this case, the more the students' brain recalls a memory, the more it will strengthen their memory. 


\section{c. Scheduled Reminders}

In learning Vocabulary the students must have a schedule of time to learn and review the lesson. The students' memories will gradually decrease over time without having a passion to learn and review the lessons regularly. So it is important for them to review what they have learned in order to keep them everlasting in their mind, in this case, Memrise will remind the students when they should practice and review the material, estimates the point at which they are about to forget it and makes their learning become more effective and efficient.

\section{Memrise is Fun learning for the Student,}

Memrise is just like a game. Most of the students like playing a game, is it right? By applying Memrise in learning and reviewing vocabulary, the students will have a fun learning experience. They can learn and review vocabulary whenever and wherever they wanted. For examples: they can learn and review vocabulary in campus, at home, at a cafe or other places. They can make time of learning and reviewing become playtime activity

We all agree most of us will learn anything easily when we are in a relaxed situation and happy mood. By applying Memrise as a learning and reviewing vocabulary tool the students will learn vocabulary in a relaxed manner, they will be happy and have no stress about what they are learning because they are learning like they are playing. So it can be said that Memrise is a good choice for them to learn vocabulary because it turned learning vocabulary into a game where it grows a colorful garden of memory.

By using "Memrise", the students can learn a new word, think of it as planting a new seed in their memory. Then every time they want to review that word, Memrise helps it to grow a little bit likes watering a little flower. By reviewing at the right time Memrise helps it grows as fast as possible and soon the students will have a glorious garden full of memories about what they have learned.

\section{a. How the Students' Memory Garden Works in Memrise}

The students need a regular and continuous vocabulary review. It is intended to keep and strengthen their memory. On Memrise, learning vocabulary was turned into a wonderful game in which the students grow a garden of memory. In this case, every word that the students will learn is assumed as a seed, and the students nurture it through reviews and tests until it grows strong, takes root and blossoms into a flower in their Long Term Memory (LTM). After it in their Long-Term Memory, the students have to review to keep it fresh in the students' mind. There are 2 stages of learning vocabulary in Memrise' garden: 1) Learning new words and 2) reviewing long-term memories. 


\section{Stage 1- The Students Learn New Words}

When the students first learn a new word, their memory requires the most love and attention. Therefore, the lecturer has to test it and remind it as often as possible Repetition and test will be helpful for them in having a long-term memory about the words that they have learned. Therefore, in Memrise there were repeated tests for helping a new memory to finish growing. Then that word can be in the students' LongTerm Memory.

\section{Stage 2-The Students Review Long-Term Memories}

If the students have totally grown a word in their garden of long-term memory, they don't need to give full attention to the word like they did when it first took place in their mind, but they still need to review it regularly. Reviewing words through "Memrise" will refresh and strengthen the students' memories and keeps them healthy forever. By doing a review to the word regularly the students will never forget what they have learned. In this case, Memrise helps them by targeting to only those words that need to be reviewed and keeping the words that that learned in their Long-Term Memory effectively.

\section{Memrise is Community learning.}

In Memrise there are various learning that the students can afford for free. There are many users that can share their idea or just learn from another user. So with Memrise' community, the students can have a good experience about a wonderland multimedia of learning, in which videos, audio, usage, mnemonics, etymologies and much more bring the learning to life. Some principles in Memrise as community learning:

\section{Together we are smarter}

There are Millions of people used memrise to learn languages. Those people are called as Memrise User. Through Memrise we can be smart people together, learn what we want to learn in an effective manner, share our ideas to help another user, have benefited from the ideas that other users have shared.

\section{a. Play works}

In Memrise there are three Watchwords of fun learning: discovery, curiosity, and surprise, those watchwords of fun learning are taking learning out of the classroom and turning it into a game. Therefore, learning and reviewing vocabulary through Memrise can become our students' favorite playtime activity. 


\section{b. Our memory is a garden, not a storehouse}

Memrise teams believe that our memory is at the heart of how we see and imagine and feel about our world. It's colorful, vibrant and dynamic, not something grey stored away at the back of our brain, or on your phone. They think memory is more like a garden than a storehouse. So they visualize each word we learn as a seed, growing into a plant; they represent our mind as a colorful garden, and our knowledge is then something we will want to tend and cultivate, to lovingly keep alive, not let wither as soon as we have passed an exam. Therefore, Memrise is an appropriate tool for the students' in learning and reviewing vocabulary.

\section{c. School shouldn't interfere with our education}

Some of Memrise team had a hard time in school, while others excelled: between them, they have flunked almost every imaginable qualification. All of them, though, feel let down by their formal education they believe learning should be something we choose to do, and that we should do it with our peers; and we reckon it is best done out of curiosity and joy, not fear and ambition. It's with this commitment to learning for the joy of it that they're building Memrise: a pleasure-garden of learning for anyone who wishes to come and play.

\section{d. Humans first and foremost}

We cannot ignore that technology has an important role in this digital era. Memrise is one of educational technology is appropriate for our students because Memrise' team commit to using technology to make the users (human) become smarter, more curious and independent by combining science, technology to help the users grow their mind. They have a belief that humanity is more wonderful than technology. Therefore, they make human or the users become their priority and they don't agree to any technology that makes the users dependent, ignorant or addicted to something meaningless.

\section{Previous Research}

There were some previous researchers on the benefit or impact of Memrise in education field especially in learning language which gave the researcher motivation and contribution to do the research or write her publication especially in the field of improving the students' low vocabulary by using Memrise such as 1) Kent and Sherman (2013) their research was "Pilot Study for Use of Memrise Application by Korean Junior College Students Studying EFL Vocabulary in a Blended Learning Context", 2) Walker(2016) has proved that Memrise has positive impact on the students " learning language on his research "The Impact of Using Memrise on Student' Perceptions of Learning Latin Vocabulary and on Long-term Memory of Words". 


\section{METHOD}

Based on the research problems and the research objectives, the researcher used CAR (Classroom Action Research) design. The researcher applied CAR because there was a problem dealing with the students' low achievement on the vocabulary test. In Pre-test the students' mean score was (60.45), it was below the minimum criterion mastery of the ESP subject (75.00). This research involved 39 students of Agriculture and Animal Husbandry at the Islamic University of Balitar. Furthermore, the researcher used CAR procedures based on Kemmis' and Taggart. According to Kemmis and Taggart (1997, P 27) in one cycle of Classroom Action Research covers some important procedures namely: (1) Planning, (2) Acting, (3) Observing and (4) Reflecting"

\section{Planning the Action}

Mistar (2010, p.31) explains that in planning there is a learning strategy that developed to solve the problems which have been decided. It refers to any activities starting from the first until the end of the teaching-learning process. In this section, the researcher did the following activities (1) Designing lesson plan, (2) Preparing Materials and teaching strategy in this case the researcher made a vocabulary course which covered all 3 levels of the targeted vocabularies that the students must learn.(Further information about the researcher's vocabulary course see at https://www.memrise.com/course/90393/agriculture-and-farming-vocabulary/).

Preparing Assessment (Post-Test): the test was in the form of multiple choice test which consisted of 40 items, (4) preparing questionnaire and (5) Setting criteria of success: the criteria of success in this research was designed on the basis university criterion mastery: the students were considered good or successful in their vocabulary mastery if their mean score at least 75.00 or each student got minimum score: 75 (B) in his /her test.

\section{Implementing the Action}

In this section, the researcher implemented what had been designed in the lesson plan. She asked the students learning and reviewing vocabulary using "Memrise". Mistar (2010, p.31) says that implementing the action refers to the arranged of learning strategy that has planned before". In this research there were 3 meetings, first meeting was for learning vocabulary of level 1, second meeting was for learning vocabulary of level 2 and the last meeting was for learning vocabulary of level 3.( Further information about the each level of vocabulary materials made by the researcher see at https://www.memrise.com/course/90393/agriculture-and-farming-vocabulary/)

Moreover, after the students finished their learning of each level of vocabulary course they were given reading text related to agriculture and farming and animal and plant breeding. Furthermore, at the end of the each meeting the lecturer reminded the students to do reviewing outside of the class learning (Take home reviewing vocabulary through Memrise). And in the fourth meeting, the lecturer gave the students post-test and distributing questionnaire 


\section{Observing}

In observing, the researcher collected the data indicating the success of the strategy in solving the problem. The focus of the observation is on the data consulted to the criteria of success that have been decided. It is intended to know how far the implemented strategy could improve the students' achievement (Latief, 2010, p.87). Furthermore, Mistar (2010) states that in observation, a teacher must give the explanation about the procedure of collecting data and which includes the instrument of collecting data and how they are applied.

Moreover, in this research, the researcher used 2 kinds of data collection method: (1) Administering test to know the students' improvement of the implementation of Memrise, the test was consists of 40 items in the form multiple choice, and (2) distributing questionnaire to know the students' response toward the use of "Memrise" as learning and reviewing Vocabulary tool in learning English. Furthermore, to analyze the data the researcher used 3 formulas as the following:

a. The formula to find an individual degree of mastery

$$
\text { Degree of Mastery }=\frac{\text { Number of Correct Items }}{\text { Total Number of Items }} \times 100 \%
$$

b. The formula to find the students' mean score

$$
\mathrm{M}=\frac{\sum X}{N}
$$

c. The formula for calculating the percentage of students' questionnaires responses

$$
\ldots \%=\frac{\text { The Number of Students choosing certain items }}{\text { total Number of Students }} \times 100
$$

\section{Reflecting}

Reflection is very crucial in a Classroom Action Research, it is intended to decide whether the next cycle is necessary or not. In CAR, we cannot predict how many cycles that will be applied to solve our class problem. In this case, it may take only one cycle if, in the first cycle, the students have achieved the criterion of success. However, in CAR, the teachers must do their best to plan their classroom action research as few cycles as possible.

In reflection, the researcher consults the result of data analysis with the criteria of success. If the result of the first cycle action achieves the criteria of success, the action is stopped. If it does not achieve the criteria of success, the researcher should continue to the second cycle by revising the lesson plan (Latief, 2010).

In addition, Mistar (2010. P.31) states that reflection in a classroom action research is an effort to evaluate whether the teaching-learning process succeeds or fails based on the criteria of success that have been decided before". 
In this research, reflection could be done by the researcher after finishing the research steps (Acting, Planning, and Observing). It is intended to know whether she could stop the research or should continue to another cycle. In this case, she would decide to stop the research in the first cycle, if the criterion of success of the research has been achieved by the students. In which the student's mean score in post-test should be the same with or higher than the criterion of success of the research (75.00).

\section{THE RESEARCH FINDING AND DISCUSSION}

\section{The students' Test Result}

After one cycle of action, the result of the research showed that learning and reviewing vocabulary through Memrise could improve the students' vocabulary achievement from the mean score 60.45 (Pre-test) to 85.27 (Post-test). Further information about the students' score, see the following chart:

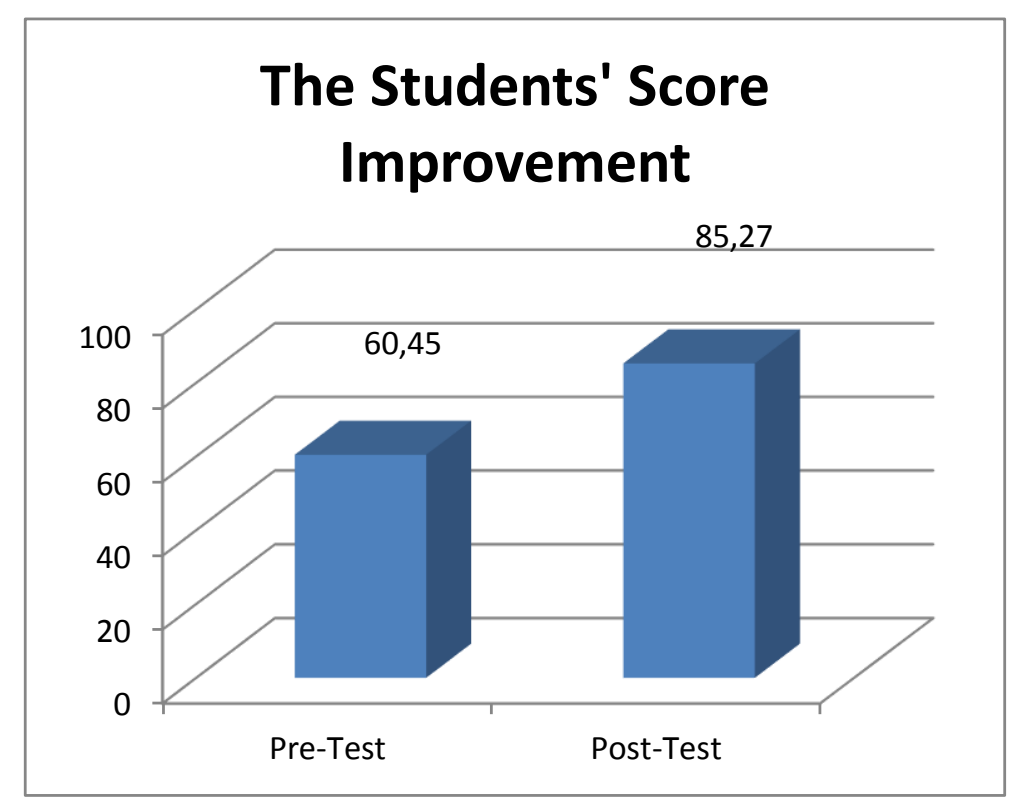

\section{The Result of Students' Questionnaires}

The data on the students' opinion towards learning and reviewing vocabulary through Memrise was obtained through distributing questionnaires (cover 10 statements) to 39 students in the second semester of Faculty of Agriculture and Animal Husbandry at the Islamic University of Balitar-Blitar. The questionnaire covered four variables to measure: (1) learning motivation, (2) learning result, (3) tasks accomplishment and (4) social relationship.

The students' questionnaire results showed that on the first variable "learning motivation", the students are motivated to learn vocabulary through Memrise. It can be seen from the result of the four statements given related to it. For the first statement (item number 1) "I am very eager to learn vocabulary through Memrise": 35 (89.74\%) students chose 
"absolutely agree" and $4(10.26 \%)$ students chose "agree". Moreover, 36 (92.30\%) students state "absolutely agree" and the rest $3(7.70 \%)$ students state "agree" with the second statement (item number 2): "Learning vocabulary through Memrise is an interesting and enjoyable activity". On the other hand, in the third option, for this variable, statement no. 6, "It is difficult for me to learn vocabulary through Memrise" 5 (12.80\%) students state "not agree", and the rest $34(87.20 \%)$ students state "absolutely not agree". Meanwhile, for the next statement (item no 7), "Learning vocabulary through Memrise is a worthless and time-consuming activity", 10 (25.64\%) students state "not agree" while the rest 29 (74.36\%) students state "absolutely not agree".

The data on the second variable was "learning result" also showed satisfactory response. There were 4 indicators representing this variable. The first indicator was the statement (item no. 3) "In my opinion learning vocabulary through Memrise can increase my vocabulary achievement". $33(84.62 \%)$ students chose "absolutely agree", $6(15.38 \%)$ students chose "agree". Second is statement no. 4, "Memrise help me learn and memorize new words easily". $36(92.30 \%)$ students' state "absolutely agree" and $3(7.70 \%)$ state "agree". The next is statement number 5, "Learning vocabulary through Memrise makes me learn words or phrases and their meaning in an interactive way". 32 (82.05\%) students state "absolutely agree" while the rest 7 (17.95\%) students state "agree". And the last indicator is the statement (item no 10), "Learning vocabulary through Memrise helps me understand reading texts easily". For this $35(89.74 \%)$ students state "absolutely agree" and $4(10.26 \%)$ students state "agree."

The third variable was "task achievement". From this variable, it also showed a good response for examples: in the statement number 8, "Learning Vocabulary through Memrise makes me motivated to do vocabulary review at home ", 34 (87.20\%) students state "absolutely agree" and $5(12.80 \%)$ students state "agree"

The last variable was "social relationship". In this variable also showed an acceptable response. It can be seen from the result of statement no. 9, "Learning vocabulary through Memrise increases togetherness among students". 36 (92.30\%) students choose "absolutely agree", and $2(5.13 \%)$ students state "agree", while 1 (2.57\%) students state "not sure".

\section{Reflection}

Based on the students' learning result in cycle I, it was proved that the students got an improvement in learning vocabulary. This improvement indicated by the following criteria, 1) the students' mean score was 86.27. It was higher than the standard minimum criterion of success (75.00). Therefore, it was decided that the next cycle was not necessary. In addition, that result was also supported by the students' positive responses toward the use of Memrise in learning Vocabulary. Furthermore, the result of the research above was strengthened by the student's positive responses toward the use of Memrise in teaching and learning vocabulary as reflected from the result of the questionnaire given. 


\section{CONCLUSION AND SUGGESTIONS}

This research dealt with learning and reviewing vocabulary through Memrise to improve the second-semester students' vocabulary achievement at Faculty of Agriculture and Husbandry at the Islamic University of Balitar East Java Indonesia. In order, the students' have a good vocabulary achievement they should learn and review the vocabulary material effectively. Memrise was a good tool for them in learning and reviewing the vocabulary prepared by the lecturer before the students have reading texts in their ESP class and Memrise also useful for reviewing the vocabulary materials outside of the classroom. The research was only limited to learning and reviewing 44 words/phrases related to the students' materials through Memrise to improve the students' vocabulary achievement. After 1 cycle of Action, the result of the research showed that learning and reviewing vocabulary through Memrise could improve the students' vocabulary achievement from the mean score 60.45 (Pre-test) to 85.27 (Post-test) Moreover, the students also gave positive responses toward the strategy applied as reflected from the result of the questionnaire given.

Considering the result of this research, the lecturer who teaches English especially vocabulary is suggested to use Memrise as learning media. Moreover, the researcher hopes that the research results will be useful as a reference for other researchers who want to conduct a research in vocabulary field. Furthermore, the result of this research might be different if it is applied in another area, therefore, to strengthen the research result firstly, it is suggested for future researchers to do a research with an experimental design to know the effectiveness of memrise in teaching vocabulary in wider scope or by using others topic. Secondly, it is suggested for the future researcher to conduct comparative research by comparing Memrise with other online applications in learning vocabulary, for example, Duolinggo, Vocabla or Quizlet.

\section{REFERENCES}

Alqahtani, M. (2015).The importance of vocabulary in language learning and how to be taught International Journal of Teaching and Education, Vol. III(3), pp. 21-34. 10.20472/TE.2015.3.3.002

Cahyono, Y.B. (2011) Using Facebook to Enhance English Department Students' Skill in Writing English Essays in Technique and Strategies to Enhance English Language Learning. Malang: State University of Malang Press.

Fisher, S. (2016, August 7). Memrise Review. Retrieved from https://www.thebalance.com/memrise-review-1357058

$\mathrm{Gu}, \mathrm{Y}$. (2003a). Vocabulary learning in the second language: person, task, context, and strategies. Electronic Journal. TESL-EJ, 7, 2, 1-26.

$\mathrm{Gu}, \mathrm{Y} .(2003 \mathrm{~b})$. Fine brush and freehand: The vocabulary learning art of two successful Chinese EFL learners.TESOL Quarterly, 37, 73-104

IRIS | Page 7: Vocabulary. (2017). Iris. peabody.vanderbilt.edu. Retrieved 14 September 2017, from https://iris.peabody.vanderbilt.edu/module/rti03-reading/cresource/q3/p07

Kemmis, S., \& Mc Taggart (1994). The Action Research Planner. Deakin University. 
Kent, D., Sherman, B. (2013). Pilot Study for Use of Memrise application by Korean junior college students studying EFL vocabulary in a blended learning context. Retrieved from https://www.researchgate.net

Laufer, B. \& P. Nation. (1999). A Vocabulary Size Test of Controlled Productive Ability. Language Testing 16, 33-51.

Latief, M.A. (2010) Tanya Jawab Metode Penelitian Pembelajaran Bahasa. Malang: UM Press.

Maximo, R. (2000). Effects of rote, context, keyword, and context/ keyword method on retention of vocabulary in EFL classroom, Language Learning, 50, 2, 385-412.

Macaro, E. (2001). Language strategies in foreign and second language classrooms. London: Continuum.

Memrise, (November 13, 2014) University College London Launch the First Annual 'Memrise Prize' Competition With \$10,000 Prize International competition challenges people to create the most powerful methodology for memorizing new information. Retrieved from http://www.prnewswire.com

Mistar, J. (2010) Pedoman Penulisan Tesis Program Pascasarjana Universitas Islam Malang. Malang: Program Pascasarjana Universitas Islam Malang.

Nation, I. S. P. (2001).Learning vocabulary in another language. Cambridge: Cambridge

University Press.

Qoyimah, N. (2011) Teaching Vocabulary through Discourse: the Step to Improve Students' Productivity Vocabulary in Teaching and Strategies to Enhance English Language learning. Malang: State University of Malang Press.

Read, J. (2000). Assessing vocabulary. United Kingdom: Cambridge University Press.

Schmitt, N. McCarthy, M. (Eds.) (1997). Vocabulary: Descriptive, Acquisition and Pedagogy. Cambridge: Cambridge University Press.

Schmitt, N. (2000). Vocabulary in language teaching. Cambridge: Cambridge University Press.

Walker, L. (2016). The impact of using Memrise on student perceptions of learning Latin vocabulary and on long-term memory of words. Journal of Classics Teaching, 16(32), 14-20. Doi: 10.1017/S2058631015000148 